\title{
Personal Norms in a Globalized World Norm-activation Processes and Reduced Clothing Consumption
}

Joanes, Tina

\author{
Document Version \\ Accepted author manuscript \\ Published in: \\ Journal of Cleaner Production \\ DOI: \\ 10.1016/j.jclepro.2018.11.191 \\ Publication date: \\ 2019

\section{License \\ CC BY-NC-ND}

Citation for published version (APA):

Joanes, T. (2019). Personal Norms in a Globalized World: Norm-activation Processes and Reduced Clothing Consumption. Journal of Cleaner Production, 212, 941-949. https://doi.org/10.1016/j.jclepro.2018.11.191

Link to publication in CBS Research Portal

\section{General rights}

Copyright and moral rights for the publications made accessible in the public portal are retained by the authors and/or other copyright owners and it is a condition of accessing publications that users recognise and abide by the legal requirements associated with these rights.

Take down policy

If you believe that this document breaches copyright please contact us (research.lib@cbs.dk) providing details, and we will remove access to the work immediately and investigate your claim. 


\title{
Personal Norms in a Globalized World: Norm-activation Processes and Reduced Clothing Consumption
}

\author{
Tina Joanes \\ Journal article (Accepted manuscript*)
}

\section{Please cite this article as:}

Joanes, T. (२०19). Personal Norms in a Globalized World: Norm-activation Processes and Reduced Clothing Consumption. Journal of Cleaner Production, 212, 941-949. https://doi.org/10.1016/j.jclepro.2018.11.191

\author{
DOl: https://doi.org/10.1016/j.jclepro.2018.11.191
}

* This version of the article has been accepted for publication and undergone full peer review but has not been through the copyediting, typesetting, pagination and proofreading process, which may lead to differences between this version and the publisher's final version AKA Version of Record.

Uploaded to CBS Research Portal: August २०२०

(C) 2019. This manuscript version is made available under the CC-BY-NC-ND 4.0 license http://creativecommons.org/licenses/by-nc-nd/4.0/ 


\begin{abstract}
Sustainable growth, through efficient technologies or sustainable innovations, has failed to deliver urgently needed changes towards genuinely sustainable production and consumption. Reducing consumption across sectors, therefore, is an imperative given the state of the environment. Correspondingly, there is a need to better understand what leads consumers to reduce their consumption. Building on the Norm Activation Model (NAM), the current study explores the expression of personal norms as well as intentions to reduce clothing consumption. It extends the NAM with the concept of identification with and care for all humanity (IWAH). By employing structural equation modeling $(\mathrm{n}=4123)$, it finds evidence for positive relationships between IWAH and NAM variables. Moreover, outcome efficacy has the strongest positive relationship with personal norms, which in turn relate to intentions for reducing consumption. Additionally, the study allows drawing implications for developing future interventions aiming at fostering reduced clothing consumption.
\end{abstract}

Keywords: Sustainable consumption, anti-consumption, degrowth, personal norms, outcome efficacy, identification with humanity 


\section{Introduction}

For decades, the consumption of goods and services has helped to meet basic physiological human needs, such as food and shelter, as well as psychological needs for e. g. gaining prestige or demonstrating individuality. Today, consumers can find an endless amount of options to fulfill those needs in a global marketplace of goods and services. At the same time, however, household consumption puts extensive pressure on the environment, accounting for approximately $60 \%$ of the global greenhouse gas emissions and 50-80\% of the total resource use (Ivanova et al., 2016).

These developments can be seen explicitly in the clothing industry (Connell, 2010; Lueg, Pedersen, \& Clemmensen, 2015) where fast fashion has become a well established and successful business model (Kim, Jung Choo, \& Yoon, 2013). Fast fashion provides growing numbers of clothing items with a short shelf life at affordable prices. The production of this vast amount of clothing puts heavy pressure on the environment, through the extensive use of energy and water. Equally, pesticides and chemicals used during the production process pollute local ecosystems (Choudhury, 2014). Often outsourced to developing countries, the production of clothing furthermore comprises major social concerns including long working hours, unsafe working conditions, child labor, payment below the minimum wage and denial of labor rights (Dickson, Loker, \& Eckman, 2009).

Against this backcloth, changing consumption patterns towards more sustainable ways of consuming clothing is of utmost importance to protect the environment and alleviate social problems. One potential avenue is changing consumer preferences towards more sustainable product alternatives. While consuming clothing made from e. g. organically grown cotton might be beneficial, it remains unclear whether this will suffice. So far, sustainable growth via more efficient technology or sustainable innovations has failed to deliver urgently needed changes towards 
genuinely sustainable production and consumption, both from an environmental as well as social justice perspective (Brown \& Vergragt, 2016; Hueting, 2010; Kalmykova, Rosado \& Patrício, 2016; Lorek \& Spangenberg, 2014; Martínez-Alier, Pascual, Vivien, \& Zaccai, 2010). Therefore, reducing overall consumption levels through buying less, or deciding not to buy specific environmentally and ethically harmful products at all, has previously caught scholarly attention. Such 'strong sustainable consumption' focusing on the problem of overconsumption, as opposed to technological solutions and 'weak sustainable consumption' (Gunderson, 2018; Lorek \& Fuchs, 2013), is a promising avenue towards the development of more sustainable societies (García-deFrutos, Ortega-Egea, \& Martínez-del-Río, 2016; Capstick, Lorenzoni, Corner, \& Whitmarsh, 2014; Clayton, Devine-Wright, Stern, et al., 2015).

The current paper focuses on consumers' efforts to reduce personal consumption based on environmental and social concerns in the area of clothing, which can be achieved by buying fewer items or by deciding to stop the purchase of clothing one deems problematic (e. g. non-consumption of virgin material clothing).

Since the behavior of society, organizations and ultimately individuals causes environmental damage, it is reasonable to consider ways of addressing the issue at the level of the individual (Clayton, Devine-Wright, Swim, et al., 2015). The Norm Activation Model (NAM) is one psychological approach to identify individual characteristics that lead to or hinder engaging in specific behaviors. In the current paper, it serves as a theoretical framework for exploring the role awareness of need, an ascription of responsibility and outcome efficacy play in developing a personal norm to reduce clothing consumption.

The environmental and social impact of clothing production often takes place far away from the point of consumption and the consumer. This results in the particular condition of psychological distance, i. e. spatial, temporal and social (Liberman \& Yaacov, 2008), between object and subject 
of the personal norm. In this context personal consumption decisions, made individually, gain normative relevance only in a global perspective. The current paper, therefore, extends the NAM with the concept of identification with humanity (IWAH), which is the categorization of oneself as part of, as well as a concern for all humanity, above and beyond one's community and nation (McFarland, Webb, \& Brown, 2012).

The contribution of the current study is threefold:

1) Theoretically, it extends the NAM with the concept of IWAH,(McFarland, Webb, \& Brown, 2012). Given the global context of clothing production and consumption, it investigates the relationship between general care for all humankind on a global scale, including those afar who are suffering the results of environmental degradation, and the expression of personal norms to reduce clothing consumption.

2) Contextually, it applies the extended NAM to a behavior highly relevant for future emission reductions, which comparatively few studies have examined in depth so far: the phenomenon of reduced consumption. It furthermore focuses on the area of clothing consumption, which, after food, transportation, and housing, ranks as the product category with the highest environmental impact. However, clothing consumption is still an understudied area of consumption.

3) Methodologically, it bases its results on a large and diverse sample of 4123 respondents across four countries (United States, Germany, Poland and Sweden), which allows insights valid for the four biggest clothing markets in different geographical areas.

\section{Conceptual Framework}

Figure 1 summarizes the proposed model for the current study. In the model, intentions to reduce personal clothing consumption are related to feelings of moral obligation to do so. 


\section{Running Head: PERSONAL NORMS IN A GLOBALIZED WORLD}

Antecedents for these personal norms are awareness of need, an ascription of responsibility and outcome efficacy. Two dimensions of IWAH - self-definition and self-investment - are both directly related to personal norms and indirectly through antecedents. Age, sex, income, and identification with community and nation are included as control variables.

\subsection{Norm Activation Theory}

The NAM (Schwartz, 1977) was originally developed in the context of pro-social behavior, but it repeatedly has been applied in the environmental behavior domain. According to the NAM, activated personal norms as feelings of personal obligation are the driving force for pro-social behavior. Previous studies mainly focus on two factors that are important for the activation of personal norms in a given situation: awareness of need and attribution of responsibility. Thereby awareness of need, in the original sense, is often labeled as awareness of consequences and both are used interchangeably (Klöckner, 2013). The assumption is that a person a) has to be aware of an existing problem, b) needs to be aware of the potential consequences of his or her behavior related to the need or problem and c) accepts a certain responsibility for these consequences. If awareness of consequences and attribution of responsibility increase, behaviors are more likely to be in line with existing personal norms (Van Liere \& Dunlap, 1978).

Schwartz initially theorized other important steps for the activation of a personal norm, e. g. the perception that there are actions which can be taken to relieve a problem (i. e. outcome efficacy) as well as the recognition of one's own capability to perform these actions (i. e. self-efficacy) (Broman Toft, Schuitema, \& Thøgersen, 2014; Harland et al. 2007; Nordlund, Jansson, \& Westin, 2016; Schwartz, 1977). Accordingly, de Groot \& Steg (2009) and Steg \& de Groot (2010) found outcome efficacy and He \& Zhan (2018) consumer effectiveness as 'the extent to which a person believes he or she can control the relevant problems' with his or her actions to be an important predictor of personal norms. 


\section{Running Head: PERSONAL NORMS IN A GLOBALIZED WORLD}

Prior studies provide evidence that the NAM is a valuable theoretical framework for the prediction of a range of pro-environmental intentions and behavior. Personal norms are linked to pro-environmental behavior intentions in various areas such as travel mode choice (Bamberg, Hunecke, \& Blöbaum, 2007), buying environmentally friendly products or organic food (Aertsens, Verbeke, Mondelaers, \& Huylenbroeck, 2009; Onwezen, Antonides, \& Bartels, 2013) and purchase of hybrid or electric vehicles (Nordlund \& Garvill, 2002). Equally, the NAM has been used in the context of intentions to reduce energy consumption (van der Werff \& Steg, 2015). The scope of the current study is to test whether the NAM can serve as a useful framework for explaining intentions to reduce personal clothing consumption. Based on previous literature, the following hypotheses are developed.

H1: There is a significant positive relationship between personal norms and intentions to reduce personal clothing consumption.

$\mathrm{H} 2$ : There is a significant positive relationship between personal norms to reduce personal clothing consumption and

2a: the awareness of environmental and ethical issues within clothing production, $2 b$ : the ascription of responsibility for these issues,

2c: outcome efficacy beliefs regarding the ability to remedy them with one's actions.

2.2. Identification with humanity as an antecedent for perceived personal obligations to act

Consumers in Western countries rarely experience the negative impacts of the production of the clothing they consume. There is a spatial, temporal and social distance between the places and subjects of production and consumption, as well as uncertainty about the actual existence of specific problems from a consumer perspective. Nevertheless, calls for individuals to act and mitigate 
environmental and social issues are as ubiquitous as they are reasonable. Noticeably, such appeals presume that consumers have some form of 'mental connection to those who are or will be threatened' (Fritsche, Barth, Jugert, Masson, \& Reese, 2017). In the following, two lines of research that inform how such a perspective of collective thinking is shaped are discussed.

Generally, humans can define themselves and their identity along different levels of inclusion as individuals (personal identity), as members of particular groups (social identity) or, at the highest level of inclusion, as members of the most inclusive group of human beings. Defining oneself as a member of a specific group and therewith the group as 'in-group' leads to behavior in favor of the group's interests (see social identity theory, Tajfel \& Turner, 1986 \& self-categorization theory, Turner, Oakes, Haslam, \& McGarty, 1994). Hence, identification with the most inclusive 'in-group' of all humans may contribute to behaviors that serve all humans, such as behaviors that tackle global environmental and social problems.

One psychological concept addressing the notion of a superordinate group of all humans is IWAH as the categorization of oneself as part of, as well as a concern for all humanity (McFarland et al., 2012). Recent research has refined the concept of IWAH and identified a two-factor structure with the two dimensions self-definition and self-investment (Reese, Proch, \& Finn, 2015; Reysen \& Hackett, 2016). Self-definition relates to defining oneself as part of the most inclusive group of all humans and group similarities, and self-investment stands for solidarity and loyalty with and proactive concern for humans all over the world.

Previous research repeatedly established links between the identification with humanity and pro-social and cooperative behaviors (Reese, 2016) as well as a felt responsibility to take action for a better world (Reysen \& Katzarska-Miller, 2013) and pro-environmental behaviors (DerKarabetian, Cao, \& Alfaro, 2014; Rosenmann, Reese, \& Cameron, 2016). An identification with the common human group was positively related to a preference for choosing a smaller fair-trade 


\section{Running Head: PERSONAL NORMS IN A GLOBALIZED WORLD}

chocolate bar as a reward instead of a bigger conventional chocolate bar (Reese \& Kohlmann, 2015). Moreover, Reese et al. (2015) could show in a laboratory setting that an experimental group with higher self-investment donated significantly more to a local and global charity than a control group.

People high in IWAH should have an increased interest in events and situations that affect humanity as a whole as well as humans in distant places, which should translate in higher knowledge about such events and situations as well as wish to learn about them. Previous research has found IWAH to be related to such a desire as well as increased actual knowledge of global concerns (McFarland, 2017). The Psychological Sense of Global Community (Malsch \& Omoto, 2007), a measure highly correlated with IWAH (McFarland \& Hornsby, 2015), was found strongly correlated to a measure of global social responsibility. Devine-Wright, Price \& Leviston (2015) found that relatively strong attachment at the global scale (defined as a strong sense of belonging to the area 'whole world') relates to an increased belief that climate change is happening and induced by humans. Together, this research points towards the significance of IWAH for behavioral intentions to act up environmental and social issues. At the same time, it shows links between IWAH and the concepts of awareness of need and ascription of responsibility from the NAM.

Somewhat contrary to this global perspective, previous research examined the effect of reducing psychological distance on concerns about and willingness to act concerning e. g. climate change. Intuitive at first glance, the results of such 'proximizing' strategies on attitudes and motivation are mixed. While some studies found lower psychological distance as well as personal experience of climate change related events linked to heightened concerns and willingness to act (Scannel \& Gifford, 2013; Spence, Poortinga, Butler, \& Pidgeon, 2011), other studies fail to show this relationship (Brügger, Dessai, Devine-Wright, Morton, \& Pidgeon, 2015; Brügger, Morton, \& Dessai, 2016; McDonald, Chai, \& Newell, 2015; Schuldt, Rickard, \& Yang, 2018). 


\section{Running Head: PERSONAL NORMS IN A GLOBALIZED WORLD}

The framework of Construal Level Theory (CLT) (Liberman \& Yaacov, 2008; Trope \& Liberman, 2010) can help to understand these inconsistencies. It theorizes that psychological distance first and foremost affects mental representations of situations or objects and the type of information that is used to evaluate them. Increased psychological distance points to an increase in higher-level construal, which leads to an evaluation of situations and objects in favor of more abstract and generalized principles as compared to contextual information. One example for generalized and decontextualized high-level principles are moral principles. Under circumstances of psychological distance, persons are therefore more inclined to base their judgments and decisions on generalized values and moral principles (Eyal, Liberman, \& Trope, 2008). This line of research highlights the possible benefits of a higher-level, abstract construal of humanity for the activation of moral principles and theoretically points towards a relationship between IWAH and personal norms.

Apart from this direct link of IWAH with personal norms, an indirect connection of IWAH with personal norms, mediated through NAM variables, is theorized. In line with the NAM, which conceptualizes awareness of need, an ascription of responsibility and outcome efficacy as antecedents to personal norms, we understand IWAH as an antecedent to awareness of need and ascription of responsibility. Concluding the following hypotheses are postulated:

H3: There is a significant positive relationship between the two IWAH components of selfdefinition and self-investment and

3a: personal norm as the felt personal obligation to reduce personal clothing consumption.

3b: awareness of need and ascription of responsibility regarding environmental and social problems of clothing production.

To my knowledge, no previous research has examined the relationship between both self- 
definition and self-investment and outcome efficacy. I do not have an a priori hypothesis about the magnitude or direction of this relationship but include it in the model for exploratory purpose.

\section{Method and Data}

\subsection{Procedure and Sample}

An online survey, administered by the research institute Qualtrics, was carried out in four countries between October 2016 and February 2017 with a target population aged 18 to 65 . The four countries are the United States as the worldwide biggest market for apparel and footwear, Germany as Europe's biggest market, Sweden as the biggest market among the Scandinavian countries and Poland as biggest Eastern European market (Euromonitor, 2017). The survey contained multiple measures to ensure data quality and eliminate careless responses, such as instructed items (e. g. "Please select strongly agree") (DeSimone, Harms, \& DeSimone, 2015). The final sample was $\mathrm{N}=4591$ with a mean age of 42.17 years $(S D=13.55)$ and $56.70 \%$ female respondents (for an extensive description of the sample see Gwozdz, Nielsen, \& Müller, 2017).

\subsection{Measurements}

Unless otherwise stated, respondents indicated what applies for them on a 7-point Likert scale from 'Strongly disagree' to 'Strongly agree'. The primary outcome variable 'reduced clothing consumption' was defined as the intention to either reduce or entirely boycott the consumption of clothing products deemed problematic. Future intention to reduce consumption was measured with the two items in the next three months, when buying clothing items, I intend to... (1) Refrain from buying clothing about which I have environmental concerns and (2) buy fewer clothing items than usually/before.

All items are listed in Appendix A. For the NAM constructs we developed our own measurements based on item formulations in previous literature (De Groot \& Steg, 2009; Nayum, Klöckner, \& Mehmetoglu, 2016). Five items measured personal norms, six items awareness of 


\section{Running Head: PERSONAL NORMS IN A GLOBALIZED WORLD}

need, ascription of responsibility and outcome efficacy each, referring to both issues of environmental and social concern. IWAH was measured by the Identification with all Humanity Scale (McFarland et al., 2012) containing nine items and respondents were asked to answer on a 5point Likert scale. Besides, we measured identification with one's community and nation. Both variables are not directly of interest but included in the model as control variables to find the unique associations of IWAH (McFarland et al., 2012). The items were identical for all three types of identification, but the phrase "People all over the world" was replaced with "my community" and e. g. "Americans" respectively. For the remainder of this paper, the focus of the measurement lies on IWAH with its two dimensions - namely self-definition and self-investment.

\subsection{Statistical analyses}

Firstly, the descriptive structure of the data was explored using STATA 14.2. Secondly, the confirmatory factor model was fitted with AMOS 24.0 to validate the a priori measurement model. The estimator was maximum likelihood, and the procedure of listwise deletion resulted in a sample size of $n=4123$ used cases. Selected observed variables, belonging to the same latent variable, were allowed to correlate if their wording indicated a possible relationship. Finally, the analysis of the structural model was conducted with maximum likelihood estimation and bootstrapping $(\mathrm{N}=$ 2000) to obtain robust standard errors. Figure 1 depicts the structural model. To account for the structure of the data as clustered in countries a multi-group comparison by country was conducted. Individual country results are not presented in the current paper, as country-specific differences are neither part of the theoretical framework nor the focus of the current analysis. However, the author of the study can provide results for the different countries on request.

\section{Results}

4.1. Descriptive results and prevalence of reduced clothing consumption behaviors 
12 Running Head: PERSONAL NORMS IN A GLOBALIZED WORLD

Descriptive statistics of all scales and control variables are depicted in Table 1. All scales show adequate reliability (Cronbach's $\alpha=.84-.97$ ) and zero-order correlations indicate significant weak to moderate positive relationships between all scales. Asked about their intention not to consume clothing deemed problematic in next three months, $37 \%$ of the participants indicated that they disagree having this intention (see Figure 2). $28 \%$ reported being neutral and 35\% reported that they agree having such an intention $(\mathrm{M}=3.81, \mathrm{SD}=1.84$, Range $=1-7)$. In comparison, $25 \%$ disagreed with having an intention to consume fewer items in the next three months. $33 \%$ remained neutral and $42 \%$ agreed to have such an intention $(\mathrm{M}=4.27, \mathrm{SD}=1.71$, Range $=1-7)($ see Table 1$)$.

\subsection{Confirmatory factor analysis and structural equation model results}

The results of the confirmatory factor analysis with ML estimator show satisfactory standardized loadings (all apart from one item > 0.79) of all indicators on their respective latent factor (for the unstandardized and standardized factor loadings see Appendix A). In line with previous research, the IWAH item "How much do you identify with (that is, feel a part of, feel love toward, have concern for) each of the following?" was excluded due to cross-loading on both selfdefinition and self-investment (Reese et al., 2015). Equally, one item of the self-definition dimension with a loading $<0.70$ was excluded from further analysis. The fit of the measurement model was overall adequate with $\chi 2(1910, \mathrm{~N}=4123)=6749.57, \mathrm{p}<0.001, \mathrm{CMIN} / \mathrm{DF}=3.53, \mathrm{NFI}$ $=.97, \mathrm{CFI}=.98, \mathrm{TLI}=0.98, \mathrm{RMSEA}=.02(90 \%$ confidence interval $=[.02, .02], \mathrm{SRMR}=.02$, suggesting the proposed factor structure is one possible representation of the given data (Iacobucci, 2010). Satisfactory Composite Reliability ( $C R \geq 0.84)$, Average Variance Extracted (AVE $\geq 0.64$ ) and Maximum Shared Variance (MSV $\leq 0.55$ ) scores for each factor established reliability, convergent and discriminant validity of the model factors (see Appendix A for details) (Hair et al., 2010). 
13 Running Head: PERSONAL NORMS IN A GLOBALIZED WORLD

In a next step, the path and proposed structural model were tested together. The fit was adequate with $\chi 2(2950, \mathrm{~N}=4123)=13502.30, \mathrm{CMIN} / \mathrm{DF}=4.58, p<0.001, \mathrm{NFI}=0.95, \mathrm{CFI}=.96, \mathrm{TLI}=$ 0.95, RMSEA $=.021(90 \%$ confidence interval $=[.02, .02]$, SRMR $=.07$. Figure 3 indicates standardized path coefficients and the explained variance of the dependent variables $\left(\mathrm{R}^{2}\right)$ for the structural part of the model. Standardized path coefficients and bootstrapped $95 \%$ confidence intervals for the standardized path coefficients are presented in Table 2.

The standardized path coefficients show a significant direct positive relationship between personal norm and the intention to not consume clothing deemed problematic $(\beta=.48, \mathrm{p}<.001)$ and consume less clothing $(\beta=.33, \mathrm{p}<.001)$, which provides evidence for the acceptance of H1. The explained variance of the former intention is $R^{2}=0.27$, of the latter $R^{2}=0.12$ (see Figure 3).

In line with $\mathrm{H} 2 \mathrm{a}, \mathrm{H} 2 \mathrm{~b}$, and $\mathrm{H} 2 \mathrm{c}$ there are significant direct positive relationships between awareness of need, an ascription of responsibility, outcome efficacy and personal norm. Outcome efficacy has the strongest relationship with personal norm $(\beta=.32, p<.001)$ and ascription of responsibility the weakest $(\beta=.04, \mathrm{p}<.05)$. The relationship between awareness of need and personal norms is significant and positive $(\beta=.15, \mathrm{p}<.001)$.

There is a positive direct relationship between personal norm and self-investment $(\beta=.14, \mathrm{p}<$ .001), partially confirming H3a. Furthermore, significant direct positive relationships are found between IWAH components and awareness of need, an ascription of responsibility and outcome efficacy. The self-investment component of IWAH is the main driver of the relationship, as indicated by higher standardized path coefficients between self-investment and awareness of need $(\beta=.32, p<.001)$ and outcome efficacy $(\beta=.30, p<.001)$. Self-definition $(\beta=.13, p<.001)$ and self-investment $(\beta=.13, \mathrm{p}<.001)$ are equally strongly associated with ascription of responsibility, but there is no significant connection between self-definition and awareness of need. The results mostly confirm $\mathrm{H} 3 \mathrm{~b}$ and shed some light on the relationship between IWAH and outcome efficacy. 


\section{Running Head: PERSONAL NORMS IN A GLOBALIZED WORLD}

\subsection{Effects of control variables}

The relationships between awareness of need, ascription of responsibility, outcome efficacy, personal norm and the IWAH components remain positive and significant after including identification with community and nation as control variables. Moreover, identification with community itself is significantly connected to awareness of need $(\beta=.12, p<.001)$, ascription of responsibility $(\beta=.12, \mathrm{p}<.001)$, outcome efficacy $(\beta=.12, \mathrm{p}<.001)$ and personal norm $(\beta=.11, \mathrm{p}$ $<.001)$. Identification with nation has a significant negative relationship with awareness of need $(\beta$ $=-.08, \mathrm{p}<.001)$ and ascription of responsibility $(\beta=-.15, \mathrm{p}<.001)$. Age is positively connected to non-consumption intention $(\beta=.05, \mathrm{p}<.01)$ and less consumption intention $(\beta=.04, \mathrm{p}<.05)$. Similarly, gender path coefficients are significant with being a woman positively connected to nonconsumption intention $(\beta=.03, \mathrm{p}<.05)$ and intention to buy less $(\beta=.06, \mathrm{p}<.001)$. Income is negatively related to personal norm $(\beta=-.03, \mathrm{p}<.05)$, non-consumption intention $(\beta=-.05, \mathrm{p}<$ $.01)$ and less consumption intention $(\beta=-.07, \mathrm{p}<.01)$.

\section{Discussion}

The current paper identifies psychological factors that are related to a person's intention to reduce their clothing consumption. The results support that felt personal norms to reduce personal clothing consumption are related to behavioral intentions. Such personal norms are also associated with awareness of need, an ascription of responsibility and outcome efficacy. The latter was found to have the strongest positive relationship with personal norms, indicating that an increase in outcome efficacy is one of the primary determinants for increased activation of personal norms to reduce personal clothing consumption. These findings are in line with previous research, particularly for energy saving behaviors (van der Werff \& Steg, 2015) as well as willingness to ban products produced by children (Steg \& Groot, 2010) or buying environmentally friendly products (Antonetti \& Maklan, 2014). Additionally, similar results are found within the application of 
Protection Motivation Theory, which includes 'the availability and effectiveness of a coping response' (Rogers, 1975, p. 97) as an important component for attitude change. For example, with respect to electrical vehicle adoption, Bockarjova \& Steg (2014) found response efficacy (i. e. the belief, that electric vehicles can help to solve problems caused by the conventional car) to be the second strongest predictor for the positive evaluation of electric vehicles and strongest predictor for acceptability of policies promoting the use of electrical vehicles. Rainear \& Christensen (2017) equally found response efficacy as the strongest predictor of behavior intention for different proenvironmental behaviors, such as driving less or turning down the thermostat.

As the current results show, IWAH is another factor contributing to the development of personal norms and thereby behavioral intentions, which is the case above and beyond ones' identification with community and nation. The results are in line with previous research, which found IWAH related to environmentally friendly behaviors (Reese, 2016; Reese \& Kohlmann, 2015; Renger \& Reese, 2016). Likewise, the current data confirm the previously found two dimensions of the identification with humanity scale, one reflecting the identification with all humanity as belonging to one common in-group and perceiving group similarities (self-definition) and another one indicating care, solidarity, and loyalty for all humanity (self-investment). Both dimensions correlate highly, and similar to previous research it is mainly self-investment that is underpinning the positive relationship between IWAH and personal norms (Reese et al., 2015). An increased self-investment does not only directly influence personal norms positively but is also positively related to increased awareness of need about environmental and social problems of clothing production, as well as increased outcome efficacy beliefs. These results directly link to recent research on compassion and sustainable clothing consumption. Geiger \& Keller (2017) found compassion to explain variance in the endorsement of sustainable clothing and willingness to pay for fair trade labeled clothing. Compassion in this context is defined as evoking emotions as well as behavioral tendencies to 
relieve the pain of people suffering, and conceptually overlaps with the self-investment component of IWAH.

In this context, two particular results require further discussion. Firstly, the non-significant relationships between self-definition and awareness of need as well as personal norms should be addressed. These findings are in line with previous research, which found the dimension of selfdefinition unrelated to e. g. justice beliefs and intention to act against global injustice (Reese et al., 2015). One preliminary explanation is that mere self-definition and a perceived similarity is not enough, but that it also needs active willingness to invest in and commitment to help all humanity to motivate action. However, interpreting these non-significant results under the lens of Construal Level Theory can add a different perspective and possible explanation. The processes of selfdefinition are different from self-investment, as they are focusing on perceiving similarities between the self and the group of all humans and ingroup homogeneity (Leach et al., 2008). Such processes potentially bring the abstract conception of humanity closer to the self, thereby reducing psychological distance. The self-investment component, however, does not necessarily reduce psychological distance but is more connected to solidarity and wanting to help the abstract group of humanity. According to Construal Level Theory, this more abstract construal of humanity would more likely allow people to act in line with their moral convictions than reduced psychological distance would.

Secondly, further elaboration is necessary for the significant positive relationships between IWAH components and outcome efficacy, which were included for explorative purposes. Based on the current research, possible explanations can only be of presumptive nature. One possible reason is that the feeling of belonging to a group raises feelings that together as a group one can help alleviate large-scale problems like e. g. environmental burden connected with clothing production and consumption. Previous research has established that manipulations increasing collective 
efficacy raise pro-environmental intention through enhancing self-efficacy in parallel (Jugert et al., 2016). As the current study has not measured collective efficacy, this idea cannot be further tested, and future research would have to analyze the connection between IWAH, collective efficacy and personal efficacy more in detail. Furthermore, in line with this thinking, research by Greenaway et al. (2015) in the context of health and well-being showed that identification with social groups (e. g. the group world citizens) is connected to greater perceived personal control. Equally, future studies should seek to understand how far this translates into the environmental domain and specifically to outcome efficacy as the perception that one's actions can have an impact on environmental and social issues.

\subsection{Practical implications}

These findings can give valuable input for e. g. NGOs or other public actors who wish to design successful interventions and communication strategies aimed at reducing overall clothing consumption and its environmental and social impacts. The current results not only show that personal norms are connected to intentions to reduce consumption, but also illustrate possible antecedents that can foster feelings of personal obligation. As a general setting, they point towards a need for carefully considering e. g. strategies to bring environmental or social issues close to the self against strategies which capitalize on psychological distance. 'Proximising' such issues translates not necessarily into more engagement. This perspective can offer new opportunities for engagement and communication techniques, which should focus more on setting the stage of solidarity with spatial and socially distant citizens of the world. For example, Reese et al. (2015) explored an experimental manipulation of IWAH by showing an image depicting 'hands and arms of obviously varying ethnic background reaching for a globe image', which should cause more perceptions of solidarity with all humans despite psychological distance than of ingroup 
homogeneity. In line with this reasoning, the intervention successfully increased self-investment among the experimental group, but not self-definition. Moreover, participants from the experimental group donated more money for both a local and global charity as compared to the control group. Increasing identification on the more abstract level of self-investment can furthermore facilitate the processing of other information on a fitting abstraction level, e. g. about distant environmental and social problems related to clothing production (Brügger et al., 2016). Increased awareness of these problems, in turn, is related to felt moral obligations to reduce clothing consumption.

Lastly and importantly, intervention strategies should focus on communicating that individual consumers' actions can have a real impact on reducing environmental and social problems (Rainear \& Christensen, 2017). Supplemented by information about concrete actions consumers can take, these messages can be promising avenues for communicating with consumers and reducing clothing consumption.

\subsection{Limitations and future studies}

The results need to be set in context within the limitations of the current study. The two main limitations are its cross-sectional design as well as reliance on self-reported measurements.

The results are of a correlational nature, and the proposed directions of relationships between different model components are assumptions that cannot be proven, i. e. cause and effect cannot be tested. Furthermore, the study only assesses intentions for future reduction of clothing consumption, and research across multiple behavior domains has repeatedly shown that it is often a long way from intention to behavior (Carrington, Zwick, \& Neville, 2015). Hence, future studies should focus on collecting longitudinal data containing information on intentions to perform a specific behavior in the future as well as on actual behavior at a later point in time. 


\section{Running Head: PERSONAL NORMS IN A GLOBALIZED WORLD}

Using self-reported data always harbors the risks of social desirability bias leading to an overor underestimation of actual intentions or behavior, which can be especially relevant for socially accepted behaviors like environmentally friendly consumption. Moreover, single items were used to measure intentions for non-consumption of items deemed problematic and less consumption. Additionally, the item formulation for reduced consumption intentions does neither contain environmental nor social concerns as reasons for reduced consumption and the wording of 'usually/before' can be understood differently for each participant. Therefore, it cannot be identified why participants decided to consume fewer items. Possible alternative explanations, such as saving money, seasonal fluctuation in one's needs or because they usually don't buy much, cannot be ruled out. Future studies, therefore, could aim at improving the measurement of reduced consumption. Thereby behavior ideally would not only be measured by recalling past behavior or intention via self-reports, but also cross-validated via observation or real-time data collection.

\subsection{Conclusion}

The current study examines psychological antecedents for the development of a felt personal obligation, or personal norm, to reduce personal clothing consumption due to environmental concerns. It furthermore assesses the connection between such a norm and intentions to reduce personal clothing consumption in the future. The proposed model is based on the NAM but extends previous studies by adding the concept of IWAH as the categorization of oneself as part of and concern for all humanity. The model fit is satisfactory, and all but two proposed relationships are significant. Together, the findings prove the usefulness of the NAM to explain personal norms for reducing personal clothing consumption, which in turn are related to consumers' indicated intention to reduce their consumption in the following three months. IWAH has proven to be a valuable addition to the traditional components of the NAM and to make a contribution as an antecedent for 
them. Given the urgency of environmental issues and the pressing need for resolving them, questions regarding the ability of consumers to leverage solutions solemnly through personal behavior changes need to be taken seriously. Focusing on individual consumers' consumption patterns can only be seen as one building block, although an important building block, towards more sustainable societies. Despite its shortcomings, the current study contributes by providing a valuable overview of psychological components that are potentially valuable in fostering consumers' intention to reduce their clothing consumption. 
Literature

Aertsens, J., Verbeke, W., Mondelaers, K., \& Huylenbroeck, G. Van. (2009). Personal determinants of organic food consumption: a review. British Food Journal, 111(10), 1140-167.

Antonetti, P., \& Maklan, S. (2014). Feelings that Make a Difference: How Guilt and Pride Convince Consumers of the Effectiveness of Sustainable Consumption Choices. Journal of Business Ethics, 124(1), 117-134.

Bamberg, S., Hunecke, M., \& Blöbaum, A. (2007). Social context, personal norms and the use of public transportation: Two field studies. Journal of Environmental Psychology, 27(3), 190-203.

Broman Toft, M., Schuitema, G., \& Thøgersen, J. (2014). Responsible technology acceptance: Model development and application to consumer acceptance of Smart Grid technology. Applied Energy, 134, 392-400.

Bockarjova, M., \& Steg, L. (2014). Can Protection Motivation Theory predict proenvironmental behavior? Explaining the adoption of electric vehicles in the Netherlands. Global Environmental Change, 28(1), 276-288.

Brown, H. S., \& Vergragt, P. J. (2016). From consumerism to wellbeing: toward a cultural transition? Journal of Cleaner Production, 132, 308-317. 
22 Running Head: PERSONAL NORMS IN A GLOBALIZED WORLD

Brügger, A., Dessai, S., Devine-Wright, P., Morton, T. A., \& Pidgeon, N. F. (2015). Psychological responses to the proximity of climate change. Nature Climate Change, 5(12), 10311037.

Brügger, A., Morton, T. A., \& Dessai, S. (2016). "Proximising” climate change reconsidered: A construal level theory perspective. Journal of Environmental Psychology, 46, 125-142.

Capstick, S., Lorenzoni, I., Corner, A., \& Whitmarsh, L. (2014). Prospects for radical emissions reduction through behavior and lifestyle change. Carbon Management, 5(4), 429-445.

Carrington, M. J., Zwick, D., \& Neville, B. (2016). The ideology of the ethical consumption gap. Marketing Theory, 16(1), 21-38.

Choudhury, A.K.R. (2014). Environmental impacts of the textile industry and its assessment through life cycle assessment. In S. S. Muthu (Ed.), Roadmap to Sustainable Textiles and Clothing Environmental and Social Aspects of Textiles and Clothing Supply Chain (pp. 1-39) Singapore: Springer.

Connell, K. Y. H. (2010). Internal and external barriers to eco-conscious apparel acquisition. International Journal of Consumer Studies, 34(3), 279-286.

Clayton, S., Devine-Wright, P., Stern, P. C., Whitmarsh, L., Carrico, A., Steg, L., Swim, J., \& Bonnes, M. (2015a). Psychological research and global climate change. Nature Climate Change, $5(7), 640-646$. 
Clayton, S., Devine-Wright, P., Swim, J., Bonnes, M., Steg, L., Whitmarsh, L., \& Carrico, A. (2015b). Expanding the Role for Psychology in Addressing Environmental Challenges. American Psychologist, 71(April 2016), 199-215.

De Groot, J. I. M., \& Steg, L. (2009). Morality and Prosocial Behavior: the Role of Awareness, Responsibility, and Norms in the Norm Activation Theory. The Journal of Social Psychology, 149(4), 425-449.

Der-Karabetian, A., Cao, Y., \& Alfaro, M. (2014). Sustainable Behavior, Perceived Globalization Impact, World-Mindedness, Identity, and Perceived Risk in College Samples from the United States, China, and Taiwan. Ecopsychology, 6(4), 218-233.

DeSimone, J. A., Harms, P. D., \& DeSimone, A. J. (2015). Best practice recommendations for data screening. Journal of Organizational Behavior, 36(2), 171-181.

Devine-Wright, P., Price, J., \& Leviston, Z. (2015). My country or my planet? Exploring the influence of multiple place attachments and ideological beliefs upon climate change attitudes and opinions. Global Environmental Change, 30, 68-79.

Dickson, M. A., Loker, S., \& Eckman, M. (2009). Social responsibility in the global apparel industry. New York: Fairchild Books.

Euromonitor International (2017). Market Sizes Apaprel and Foodwear, Historical/Forecast 
24 Running Head: PERSONAL NORMS IN A GLOBALIZED WORLD

Retail Value RSP in US\$mm. Retrieved from http://www.euromonitor.com/

Eyal, T., Liberman, N., \& Trope, Y. (2008). Judging near and distant virtue and vice. Journal of Experimental Social Psychology, 44(4), 1204-1209.

Fritsche, I., Barth, M., Jugert, P., Masson, T., \& Reese, G. (2018). A Social Identity Model of Pro-Environmental Action (SIMPEA). Psychological Review, 125(2), 245-269.

García-de-Frutos, N., Ortega-Egea, J. M., \& Martínez-del-Río, J. (2016). Anti-consumption for Environmental Sustainability: Conceptualization, Review, and Multilevel Research Directions. Journal of Business Ethics, 1-25.

Geiger, S. M., \& Keller, J. (2017). Shopping for Clothes and Sensitivity to the Suffering of Others: The Role of Compassion and Values in Sustainable Fashion Consumption. Environment and Behavior, 1-26.

Greenaway, K. H., Haslam, S. A., Cruwys, T., Branscombe, N. R., Ysseldyk, R., \& Heldreth, C. (2015). From "we" to "me": Group identification enhances perceived personal control with consequences for health and well-being. Journal of Personality and Social Psychology, 109(1), 5374.

Gunderson, R. (2018). Degrowth and other quiescent futures: Pioneering proponents of an idler society. Journal of Cleaner Production, 198, 1574-1582. 
25 Running Head: PERSONAL NORMS IN A GLOBALIZED WORLD

Gwozdz, W., Nielsen, K. S., \& Müller, T. (2017). An Environmental Perspective on Clothing Consumption: Consumer Segments and Their Behavioral Patterns. Sustainability, 9(5), 762-789.

Hair, J., Black, W., Babin, B., and Anderson, R. (2010). Multivariate data analysis (7th ed.): Prentice-Hall, Inc. Upper Saddle River, NJ, USA.

Harland, P., Staats, H., \& Wilke, H. A. M. (2007). Situational and Personality Factors as Direct or Personal Norm Mediated Predictors of Pro-environmental Behavior: Questions Derived From Norm-activation Theory. Basic and Applied Social Psychology, 29(4), 323-334.

He, X., \& Zhan, W. (2018). How to activate moral norm to adopt electric vehicles in China? An empirical study based on extended norm activation theory. Journal of Cleaner Production, 172, $3546-3556$.

Hueting, R. (2010). Why environmental sustainability can most probably not be attained with growing production. Journal of Cleaner Production, 18(6), 525-530.

Iacobucci, D. (2010). Structural equations modeling: Fit Indices, sample size, and advanced topics. Journal of Consumer Psychology, 20(1), 90-98.

Ivanova, D., Stadler, K., Steen-Olsen, K., Wood, R., Vita, G., Tukker, A., \& Hertwich, E. G. (2016). Environmental Impact Assessment of Household Consumption. Journal of Industrial Ecology, 20(3), 526-536. 
Jugert, P., Greenaway, K. H., Barth, M., Büchner, R., Eisentraut, S., \& Fritsche, I. (2016). Collective efficacy increases pro-environmental intentions through increasing self-efficacy. Journal of Environmental Psychology, 48, 12-23.

Kalmykova, Y., Rosado, L., \& Patrício, J. (2016). Resource consumption drivers and pathways to reduction: economy, policy and lifestyle impact on material flows at the national and urban scale. Journal of Cleaner Production, 132, 70-80.

Kim, H., Jung Choo, H., \& Yoon, N. (2013). The motivational drivers of fast fashion avoidance. Journal of Fashion Marketing and Management: An International Journal, 17(2), 243-260.

Klöckner, C. A. (2013). A comprehensive model of the psychology of environmental behaviour-A meta-analysis. Global Environmental Change, 23(5), 1028-1038.

Leach, C. W., van Zomeren, M., Zebel, S., Vliek, M. L. W., Pennekamp, S. F., Doosje, B., ... Spears, R. (2008). Group-level self-definition and self-investment: A hierarchical (multicomponent) model of in-group identification. Journal of Personality and Social Psychology, 95(1), 144-165.

Liberman, N., \& Yaacov, T. (2008). The Psychology of Transcending the Here and Now. Science, 322(5905), 1201-1205.

Lorek, S., \& Fuchs, D. (2013). Strong sustainable consumption governance - Precondition for a degrowth path? Journal of Cleaner Production, 38, 36-43. 
27 Running Head: PERSONAL NORMS IN A GLOBALIZED WORLD

Lorek, S., \& Spangenberg, J. H. (2014). Sustainable consumption within a sustainable economy - Beyond green growth and green economies. Journal of Cleaner Production, 63, 33-44.

Lueg, R., Pedersen, M. M., \& Clemmensen, S. N. (2015). The Role of Corporate Sustainability in a Low-Cost Business Model - A Case Study in the Scandinavian Fashion Industry. Business Strategy and the Environment, 24(5), 344-359.

Malsch, A. M., \& Omoto, A. M. (2007). Prosocial behavior beyond borders: Understanding a psychological sense of global community. Claremont, CA: Unpublished manuscript, Department of Psychology, Claremont Graduate University

Martínez-Alier, J., Pascual, U., Vivien, F. D., \& Zaccai, E. (2010). Sustainable de-growth: Mapping the context, criticisms and future prospects of an emergent paradigm. Ecological Economics, 69(9), 1741-1747.

McDonald, R. I., Chai, H. Y., \& Newell, B. R. (2015). Personal experience and the "psychological distance" of climate change: An integrative review. Journal of Environmental Psychology, 44, 109-118.

McFarland, S., \& Hornsby, W. (2015). An analysis of five measures of global human identification. European Journal of Social Psychology, 45(7), 806-817.

McFarland, S. (2017). Identification with all humanity: The antithesis of prejudice, and more. In S. G. Sibley \& F, K. Barlow (Eds.), Cambridge Handbook on the Psychology of Prejudice (pp. 632- 
28 Running Head: PERSONAL NORMS IN A GLOBALIZED WORLD

654). New York: Cambridge University Press.

McFarland, S., Webb, M., \& Brown, D. (2012). All humanity is my ingroup: A measure and studies of identification with all humanity. Journal of Personality and Social Psychology, 103(5), $830-853$.

Nayum, A., Klöckner, C. A., \& Mehmetoglu, M. (2016). Comparison of socio-psychological characteristics of conventional and battery electric car buyers. Travel Behaviour and Society, 3, 820.

Nordlund, A., Jansson, J., \& Westin, K. (2016). New Transportation Technology: Norm Activation Processes and the Intention to Switch to an Electric/Hybrid Vehicle. Transportation Research Procedia, 14, 2527-2536.

Nordlund, A. M., \& Garvill, J. (2002). Value Structures behind Proenvironmental Behavior. Environment and Behavior, 34(6), 740-756.

Onwezen, M. C., Antonides, G., \& Bartels, J. (2013). The Norm Activation Theory: An exploration of the functions of anticipated pride and guilt in pro-environmental behaviour. Journal of Economic Psychology, 39, 141-153.

Rainear, A. M., \& Christensen, J. L. (2017). Protection Motivation Theory as an Explanatory Framework for Proenvironmental Behavioral Intentions. Communication Research Reports, 34(3), 239-248. 
29 Running Head: PERSONAL NORMS IN A GLOBALIZED WORLD

Reese, G. (2016). Common human identity and the path to global climate justice. Climatic Change, 134(4), 521-531.

Reese, G., \& Kohlmann, F. (2015). Feeling Global, Acting Ethically: Global Identification and Fairtrade Consumption. The Journal of Social Psychology, 155(2), 98-106.

Reese, G., Proch, J., \& Finn, C. (2015). Identification With All Humanity: The role of selfdefinition and self-investment. European Journal of Social Psychology, 45, 426-440.

Renger, D., \& Reese, G. (2017). From Equality-Based Respect to Environmental Activism: Antecedents and Consequences of Global Identity. Political Psychology, 38(5), 867-879.

Reysen, S., \& Hackett, J. (2016). Further Examination of the Factor Structure and Validity of the Identification with All Humanity Scale. Current Psychology, 35(4), 711-719.

Reysen, S., \& Katzarska-Miller, I. (2013). A model of global citizenship: Antecedents and outcomes. International Journal of Psychology, 48(5), 858-870.

Rogers, R. W. (1975). A Protection Motivation Theory of fear appeals and attitude change. The Journal of Psychology, 91(1975), 93-114.

Rosenmann, A., Reese, G., \& Cameron, J. E. (2016). Social Identities in a Globalized World: Challenges and Opportunities for Collective Action. Perspectives on Psychological Science, 11(2), 
Scannell, L., \& Gifford, R. (2013). Personally Relevant Climate Change: The Role of Place Attachment and Local Versus Global Message Framing in Engagement. Environment and Behavior, $45(1), 60-85$.

Schuldt, J. P., Rickard, L. N., \& Yang, Z. J. (2018). Does reduced psychological distance increase climate engagement? On the limits of localizing climate change. Journal of Environmental Psychology, 55, 147-153.

Schwartz, S. H. (1977). Normative influences on altruism. In L. Berkowitz (Ed.), Advances in experimental psychology (Volume 10) (221-279). New York: Academic Press

Spence, A., Poortinga, W., Butler, C., \& Pidgeon, N. F. (2011). Perceptions of climate change and willingness to save energy related to flood experience. Nature Climate Change, 1(1), 46-49.

Steg, L., \& de Groot, J. (2010). Explaining prosocial intentions : Testing causal relationships in the norm activation model. British Journal of Social Psychology, 49, 725-743.

Tajfel, H., \& Turner, J. C. (1986). The social identity theory of intergroup behavior. In S. Worchel \& W. G. Austin (Eds.), Psychology of intergroup relations (pp. 7-24). Chicago, IL: Nelson.

Trope, Y., \& Liberman, N. (2010). Construal-Level Theory of Psychological Distance. 
31 Running Head: PERSONAL NORMS IN A GLOBALIZED WORLD

Psychological Review, 117(2), 440-463.

Turner, J. C., Oakes, P. J., Haslam, S. A., \& McGarty, C. A. (1994). Self and collective: Cognition and social context. Personality and Social Psychology Bulletin, 20, 454- 463.

van der Werff, E., \& Steg, L. (2015). One model to predict them all: Predicting energy behaviours with the norm activation model. Energy Research and Social Science, 6, 8-14.

Van Liere, K. D., \& Dunlap, R. E. (1978). Moral Norms and Environmental Behavior: An Application of Schwartz's Norm-Activation Model to Yard Burning. Journal of Applied Social Psychology, 8(2), 174-188. 


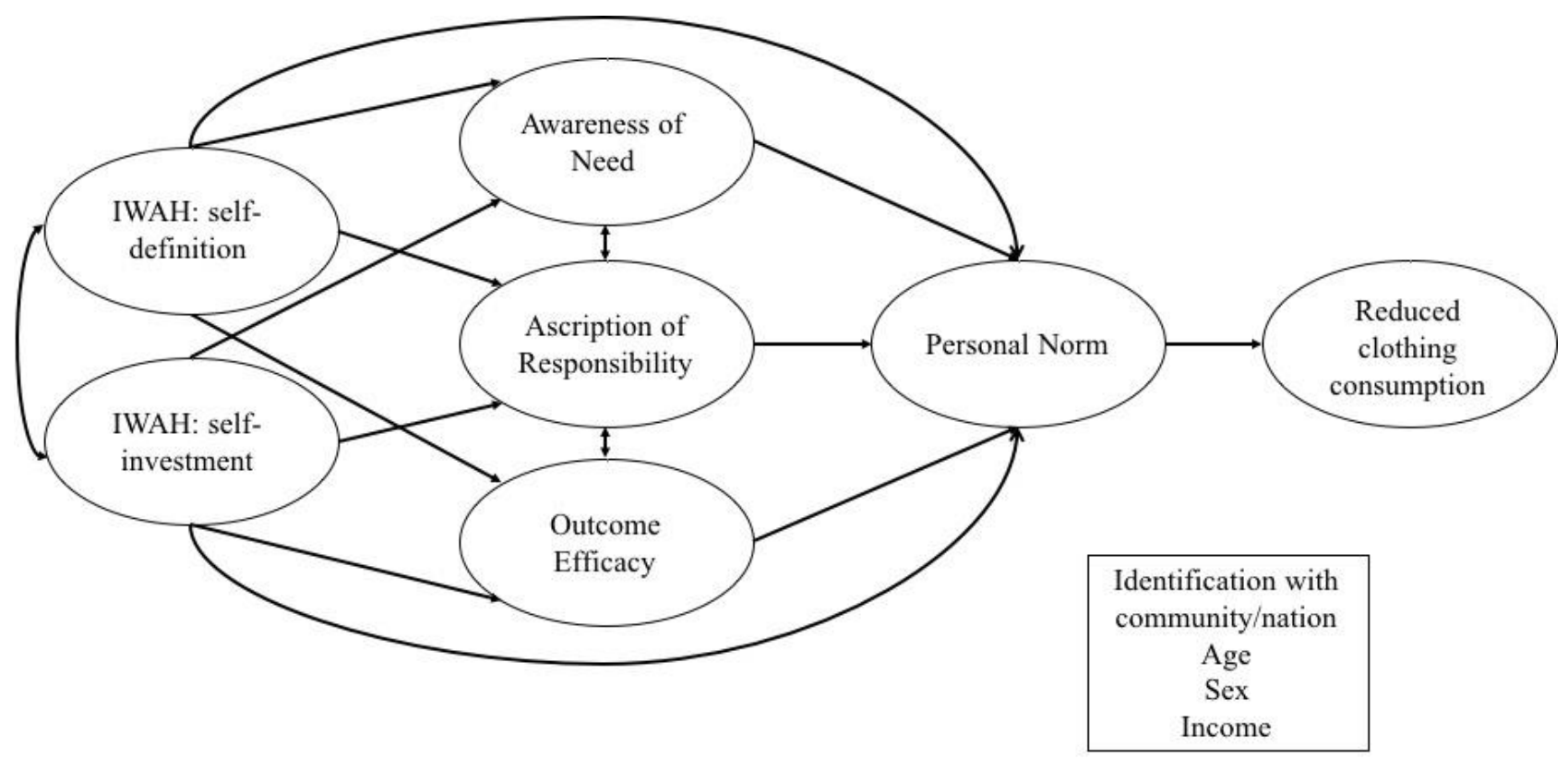

Figure 1 Proposed structural model (IWAH: Identification with all Humanity)

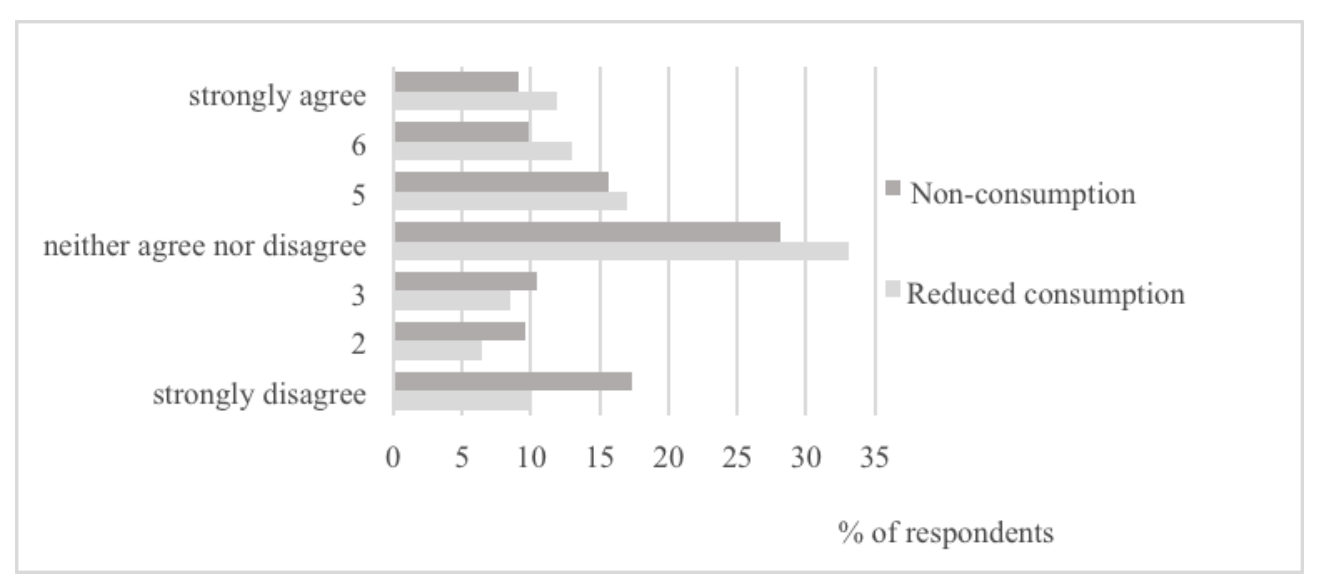

Figure 2 Prevalence of intention to reduce clothing consumption in the next three months 
Table 1 Descriptive results

\begin{tabular}{|c|c|c|c|c|c|c|c|c|c|c|c|c|c|}
\hline Scale & $\mathrm{M}$ & SD & Range & 1 & 2 & 3 & 4 & 5 & 6 & 7 & 8 & $\mathrm{C} 1$ & $\mathrm{C} 2$ \\
\hline $\begin{array}{l}\text { (1) IWAH: Self- } \\
\text { definition (SD) }\end{array}$ & 2.68 & 0.89 & $1-5$ & $\alpha=.84$ & & & & & & & & & \\
\hline $\begin{array}{l}\text { (2) IWAH: Self- } \\
\text { investment (SI) }\end{array}$ & 3.40 & 0.98 & $1-5$ & 0.64 & $\alpha=.89$ & & & & & & & & \\
\hline $\begin{array}{l}\text { (3) Awareness of } \\
\text { need (AN) }\end{array}$ & 5.45 & 1.29 & $1-7$ & 0.23 & 0.30 & $\alpha=.94$ & & & & & & & \\
\hline $\begin{array}{l}\text { (4) Ascription of } \\
\text { responsibility } \\
\text { (AR) }\end{array}$ & 4.18 & 1.61 & $1-7$ & 0.19 & 0.19 & 0.42 & $\alpha=.96$ & & & & & & \\
\hline $\begin{array}{l}\text { (5) Outcome } \\
\text { efficacy (OE) }\end{array}$ & 4.58 & 1.58 & $1-7$ & 0.34 & 0.38 & 0.43 & 0.38 & $\alpha=.97$ & & & & & \\
\hline $\begin{array}{l}\text { (6) Personal norm } \\
\text { (PN) }\end{array}$ & 4.18 & 1.74 & $1-7$ & 0.28 & 0.34 & 0.36 & 0.26 & 0.47 & $\alpha=.95$ & & & & \\
\hline \multicolumn{14}{|l|}{ Intention } \\
\hline $\begin{array}{l}\text { (7) Non- } \\
\text { consumption }\end{array}$ & 3.81 & 1.84 & $1-7$ & 0.30 & 0.34 & 0.32 & 0.21 & 0.42 & 0.48 & 1.00 & & & \\
\hline $\begin{array}{l}\text { (8) Less } \\
\text { consumption }\end{array}$ & 4.27 & 1.72 & $1-7$ & 0.09 & 0.13 & 0.15 & 0.11 & 0.21 & 0.34 & 0.35 & 1.00 & & \\
\hline $\begin{array}{l}\text { C1 Identification } \\
\text { with community }\end{array}$ & 3.35 & 0.83 & $1-5$ & 0.37 & 0.42 & 0.19 & 0.12 & 0.27 & 0.26 & 0.17 & 0.09 & $\alpha=.91$ & \\
\hline $\begin{array}{l}\text { C2 Identification } \\
\text { with nation }\end{array}$ & 3.39 & 0.78 & $1-5$ & 0.39 & 0.47 & 0.14 & $0.04^{1}$ & 0.24 & 0.21 & 0.13 & 0.08 & 0.68 & $\alpha=.90$ \\
\hline C3 Female & 0.57 & 0.50 & $0-1$ & & & & & & & & & & \\
\hline C4 Age (years) & 42.52 & 13.56 & $18-65$ & & & & & & & & & & \\
\hline $\begin{array}{l}\text { C5 Income (11 } \\
\text { categories) }\end{array}$ & 4.69 & 3.15 & $0-1$ & & & & & & & & & & \\
\hline
\end{tabular}

Note. IWAH: Identification with all Humanity; C: control variables; $\mathrm{n}=4123$; all but one correlations are significant with $\mathrm{p} \leq$ $.001\left({ }^{1} \mathrm{p} \leq .05\right)$ 


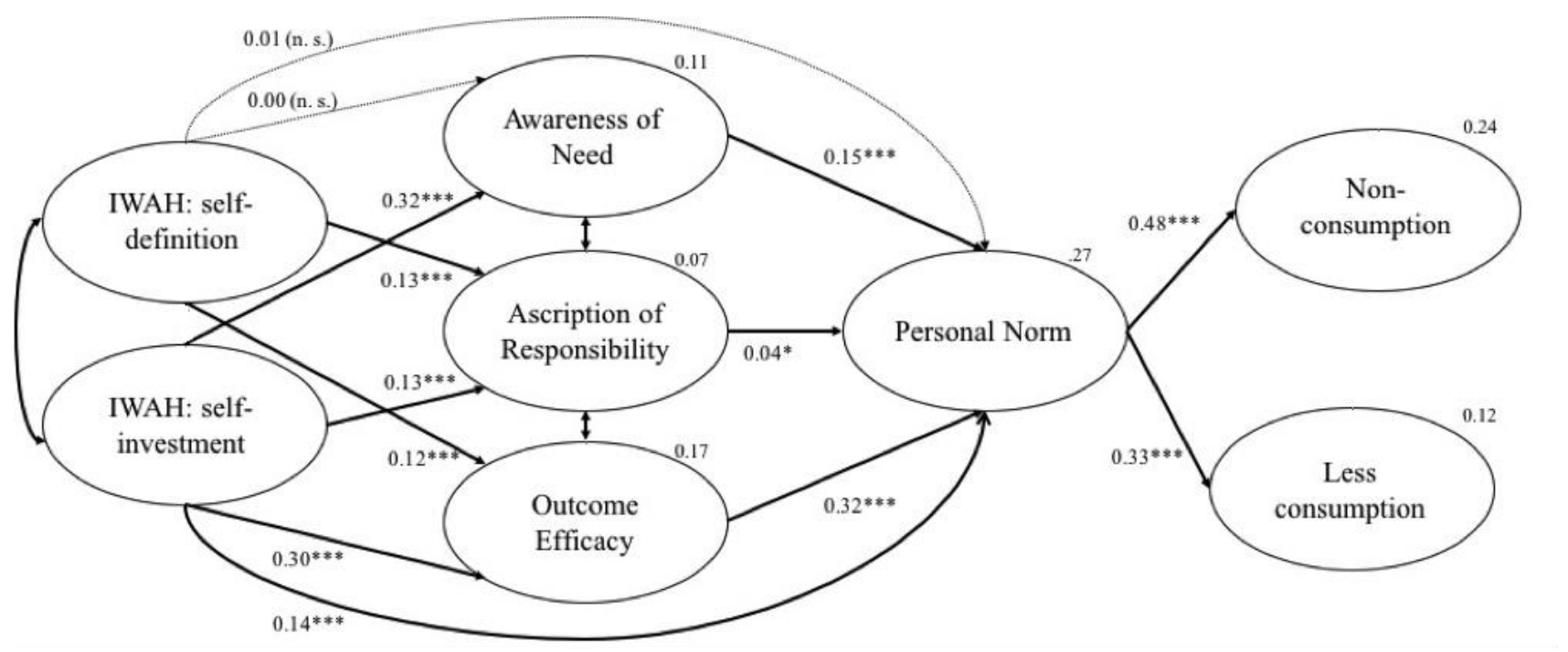

Figure 3 Structural model with standardized path coefficients, bootstrapped standard errors $(n=2000)$ and multiple squared correlations $\left(\mathrm{R}^{2}\right)$ for dependent variables at the top right corner; $* * * p<0.001 * * \mathrm{p}<0.01{ }^{*} \mathrm{p}<0.05$ (IWAH: Identification with all Humanity) 
35 Running Head: PERSONAL NORMS IN A GLOBALIZED WORLD

Table 2 Standardized path coefficients for the full structural equation model

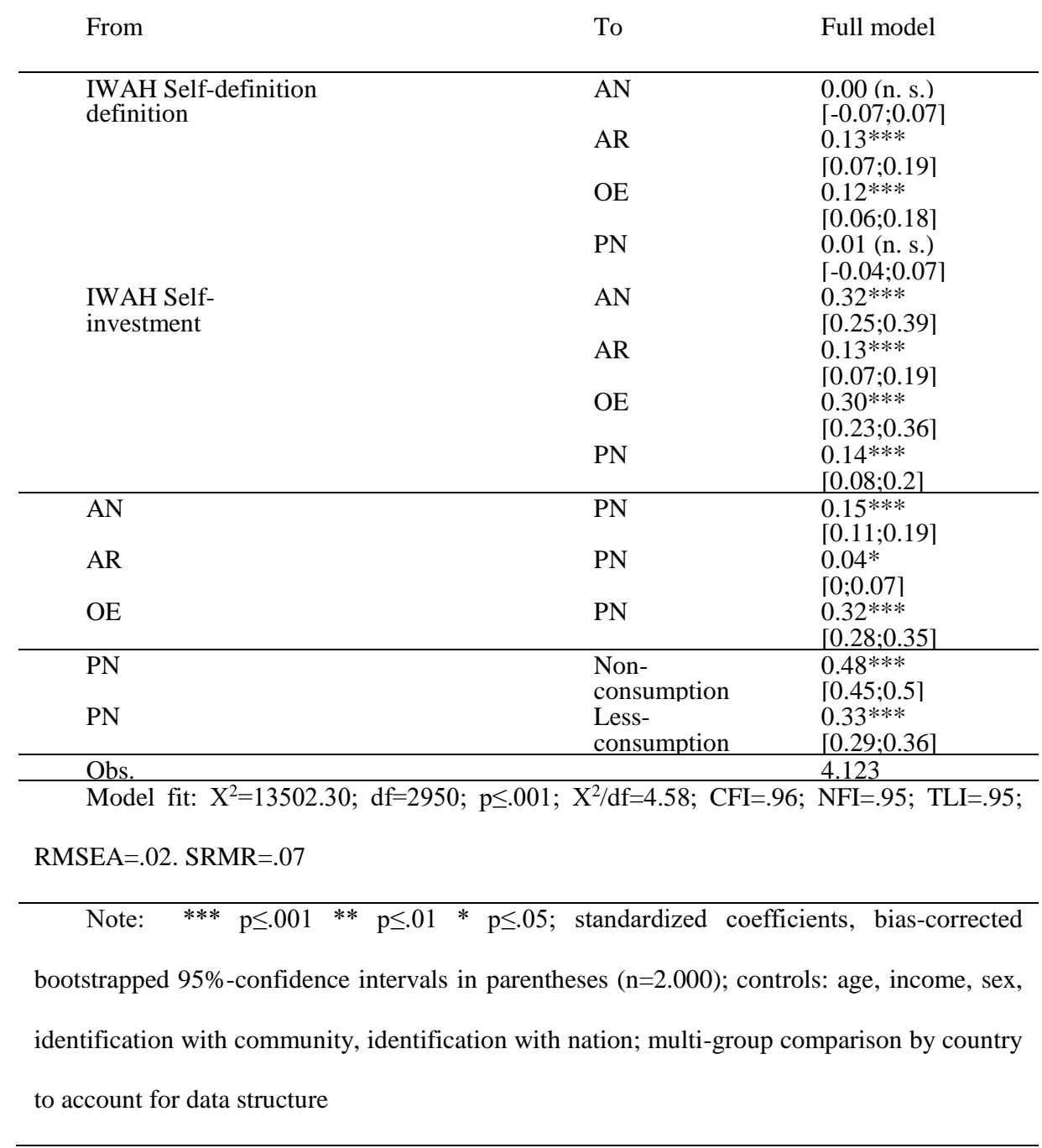


36 Running Head: PERSONAL NORMS IN A GLOBALIZED WORLD

\section{Appendix A}

\begin{tabular}{|c|c|c|c|c|c|c|}
\hline & & B & S. E. & $\mathrm{p}$ & beta & 95\%-confidence interval \\
\hline \multicolumn{2}{|r|}{$(\mathrm{CR}=0.95, \mathrm{AVE}=0.78, \mathrm{MSV}=0.19)$} & \multicolumn{4}{|c|}{ Personal norm } & \\
\hline$\rightarrow$ & $\begin{array}{l}\text { I feel obliged to reduce my personal clothing } \\
\text { consumption because of my personal values }\end{array}$ & 1 & & & 0.92 & {$[0.91 ; 0.93]$} \\
\hline \multirow[t]{2}{*}{$\rightarrow$} & $\begin{array}{l}\text { No matter what other people think or do, my } \\
\text { principles tell me that it is right to reduce my }\end{array}$ & 0.89 & 0.01 & $* * *$ & 0.85 & {$[0.83 ; 0.86]$} \\
\hline & personal clothing consumption & & & & & \\
\hline$\rightarrow$ & $\begin{array}{l}\text { Reducing my personal clothing consumption } \\
\text { is the right thing to do }\end{array}$ & 0.85 & 0.01 & $* * *$ & 0.80 & {$[0.78 ; 0.81]$} \\
\hline$\rightarrow$ & $\begin{array}{l}\text { I feel morally obliged to reduce my personal } \\
\text { clothing consumption }\end{array}$ & 0.99 & 0.01 & $* * *$ & 0.92 & {$[0.90 ; 0.93]$} \\
\hline$\rightarrow$ & $\begin{array}{l}\text { I feel a strong personal obligation to reduce } \\
\text { my personal clothing consumption }\end{array}$ & 1 & 0.01 & $* * *$ & 0.93 & {$[0.92 ; 0.94]$} \\
\hline \multicolumn{7}{|c|}{ Awareness of need (Clothing production...) } \\
\hline \multicolumn{7}{|c|}{$(\mathrm{CR}=0.94, \mathrm{AVE}=0.73, \mathrm{MSV}=0.12)$} \\
\hline$\rightarrow$ & Uses vast amounts of energy and water & 1 & & & 0.83 & {$[0.81 ; 0.84]$} \\
\hline$\rightarrow$ & Causes tremendous harm to the environment & 1.13 & 0.02 & $* * *$ & 0.88 & {$[0.87 ; 0.89]$} \\
\hline$\rightarrow$ & Uses vast amounts of hazardous chemicals & 1.09 & 0.02 & $* * *$ & 0.88 & {$[0.87 ; 0.89]$} \\
\hline$\rightarrow$ & Operates under unsafe working conditions & 1.01 & 0.02 & $* * *$ & 0.82 & {$[0.80 ; 0.83]$} \\
\hline$\rightarrow$ & $\begin{array}{l}\text { Operates under precarious employment } \\
\text { conditions }\end{array}$ & 0.95 & 0.02 & $* * *$ & 0.79 & {$[0.76 ; 0.80]$} \\
\hline$\rightarrow$ & $\begin{array}{l}\text { Impairs the health of people living in the } \\
\text { production countries }\end{array}$ & 1.11 & 0.02 & $* * *$ & 0.87 & {$[0.85 ; 0.88]$} \\
\hline \multicolumn{7}{|c|}{$\begin{array}{l}\text { Ascription of responsibility (Through my personal } \\
\text { clothing consumption, I...) }\end{array}$} \\
\hline$(\mathrm{Cr}$ & $0.96, \mathrm{AVE}=0.81, \mathrm{MSV}=0.05)$ & & & & & \\
\hline$\rightarrow$ & $\begin{array}{l}\text { Am contributing to the harm done to the } \\
\text { environment }\end{array}$ & 1 & & & 0.91 & {$[0.90 ; 0.92]$} \\
\hline
\end{tabular}


$\rightarrow \quad$ Am contributing to the amount of energy and water used in clothing production

$\begin{array}{lllll}0.96 & 0.01 & * * * & 0.88 & {[0.86 ; 0.89]} \\ & & & & \\ 1.04 & 0.01 & * * * & 0.93 & {[0.92 ; 0.94]} \\ & & & & \\ 1.03 & 0.01 & * * * & 0.92 & {[0.91 ; 0.93]}\end{array}$
people living in countries that produce clothing

$1.03-0.01-0.92$

$[0.91 ; 0.93]$

$\rightarrow \quad$ Am partly responsible for unsafe working conditions

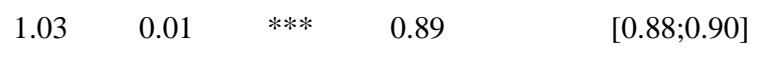

$\rightarrow$ Am supporting precarious employment conditions

Outcome efficacy (Through my personal clothing consumption, I can...)

$(\mathrm{CR}=0.96, \mathrm{AVE}=0.81, \mathrm{MSV}=0.19)$

$\rightarrow \quad$ reduce the environmental impact

$1+0.89$

$[0.88 ; 0.91]$

$\rightarrow \quad$ have an impact on water and energy savings

$0.98 \quad 0.01 \quad * * * \quad 0.88$

[0.86;0.89]

$\rightarrow$ have an impact on reducing the use of hazardous chemicals

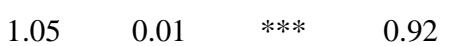

$[0.91 ; 0.93]$

$\rightarrow \quad$ influence improvements in working conditions

$1.04 \quad 0.01 \quad * * * \quad 0.90$

$[0.89 ; 0.92]$

$\rightarrow \quad$ influence improvements in the health of people living in production countries

$1.04 \quad 0.01 \quad * * * \quad 0.91$

$[0.89 ; 0.92]$

$\rightarrow$ influence improvements in precarious employment conditions (e.g. child labor. long working hours. and low wages)

IWAH: Self-definition

$(\mathrm{CR}=0.84, \mathrm{AVE}=0.64, \mathrm{MSV}=0.55)$

$\rightarrow \quad$ How close do you feel to people all over the world?

$\rightarrow \quad$ How often do you use the word 'we' to refer to people all over the world?

$\begin{array}{lllll}1.14 & 0.02 & * * * & 0.79 & {[0.77 ; 0.81]} \\ & & & & \\ 1.03 & 0.02 & * * * & 0.83 & {[0.82 ; 0.85]}\end{array}$

$\rightarrow$ How much would you say you have in common with people all over the world?

IWAH: Self-investment

$(\mathrm{CR}=0.89, \mathrm{AVE}=0.67, \mathrm{MSV}=0.55)$ 


\section{Running Head: PERSONAL NORMS IN A GLOBALIZED WORLD}

$\rightarrow \quad$ How much would you say you care (feel upset. want to help) when bad things happen to people anywhere in the world?

$\rightarrow \quad$ How much do you want to be a responsible citizen of the world?

$\begin{array}{lllll}0.99 & 0.02 & * * * & 0.8 & {[0.77 ; 0.81}\end{array}$

$\rightarrow \quad$ How much do you believe in being loyal to all mankind?

$\begin{array}{lllll}1.01 & 0.02 & * * * & 0.78 & {[0.76 ; 0.80}\end{array}$

$\rightarrow \quad$ When they are in need, how much do you want to help people all over the world?

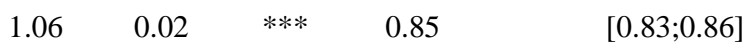

Note: $* * * \mathrm{p} \leq .001 * * \mathrm{p} \leq .01 * \mathrm{p} \leq .05$; bias-corrected bootstrapped 95\%-confidence intervals in parentheses $(\mathrm{n}=2.000)$ 